\title{
Is occult Hepatitis B virus infection with detectable anti-HBs infectious or not?
}

\author{
Murat Afyon $^{1 *}$, Cumhur Artuk ${ }^{2}$
}

1. GATA Haydarpasa Training Hospital, First Step Examination, Family Health Center And The Naval Academy Clinic Tuzla / Istanbul, Turkey.

2. GATA Training and Research Hospital, Department of Infectious Diseases, Kecioren/Ankara, Turkey

Please cite this paper as:

Afyon M, Artuk C. Is occult Hepatitis B virus infection with detectable anti-HBs infectious or not?. Middle East J Dig Dis 2016;8:147-149. DOI :10.15171/mejdd.2016.21

In the recent issue of Middle East Journal of Digestive Diseases, we read with great interest the article by Bahari et al. ${ }^{1}$, "Significance of response to hepatitits B vaccine in subjects with isolated antibody to hepatitis B core antigen". We wanted to specify some important matters related to the article.

Initially, definition of occult hepatitis B virus infection is the existence of hepatitis B virus (HBV) deoxyribonucleic acid (DNA) in the liver of individuals negative for hepatitis B surface antigen ( $\mathrm{HBsAg}$ ) by currently available assays. ${ }^{2}$ Serum HBV DNA titres may be detectable (usually very low, $<200$ $\mathrm{IU} / \mathrm{ml}$ ) or undetectable, and may show fluctuation in occult hepatitis B virus infection patients. Also, occult hepatitis B virus infection may occur not only seropositive for antibodies to hepatitis B core antigen (anti-HBc) and/or antibodies to HBsAg (anti-HBs), but also seronegative. ${ }^{2}$

Isolated anti-HBc positivity or anti-HBc alone, most commonly associated with occult hepatitis B virus infection, develops particularly because of the reduction of corresponding antibodies to undetectable levels after the resolution of infection. ${ }^{3}$ In this case, with HBV vaccination as implemented in the article, anti-HBs levels increase in a short time. ${ }^{1}$ However, isolated anti-HBc positivity can be seen in the begining of the convalescene period of current infection or with the reduction of HBsAg to undetectable levels after long-term inactive HBV carriage. The reduction of HBsAg levels can be shown by only high sensitive HBsAg assays and may be with low HBV DNA titres. Moreover, false isolated anti-HBc positivity has been reported up to $35 \%$ via repetitive tests. 4,5

The more important topic is whether occult hepatitis B virus infection with detectable anti-HBs is infectious or not. Theoretically, high anti-HBs titres can neutralize the infectivity of virus particles, on the other hand, infection can emerge if the product to be transfused is positive for HBV DNA. HBV transmission from patients with occult hepatitis B virus infection with antiHBs positivity to immunocompetent recipients has been shown. ${ }^{6}$ In addition, it has also been reported that anti-HBs titres lower than $100 \mathrm{IU} / \mathrm{ml}$ have insufficient protectivity in the presence of HBV DNA and products containing HBV DNA may be infectious and may cause serious clinical status in patients with severe immun deficiency even though anti-HBs levels are high. ${ }^{6}$ Anti$\mathrm{HBc}$ positive donations are accepted only if HBV DNA is negative and antiHBs titres are at least $100 \mathrm{IU} / \mathrm{ml}$ in European Union countries and at least 200 $\mathrm{IU} / \mathrm{ml}$ in Japan. ${ }^{7,8}$

Consequently, serological tests and vaccination of solely anti- $\mathrm{HBc}$ donors 
might be an option or tool for donor screening, but a combination of serological tests with nucleic acid amplification tests (indivudalize or at least pooled) seems more reasonable and reliable for the reasons mentioned above (e.g., seronegative occult hepatitis B virus infection, isolated anti-HBc positivity due to the reduction of HBsAg titres with low HBV DNA levels, donor loss because of the false isolated anti-HBc positivity and infectivity of occult hepatitis B virus infection with detectable anti-HBs). However, the costs, the need for equipment, and experienced staff or accessibility may be the problems as shared by Bahari et al. ${ }^{1}$

\section{ACKNOWLEDGMENTS}

The contents of the paper are the sole responsibility of the author and do not necessarily represent the official views of any institute or organization.

\section{CONFLICT OF INTEREST}

The author declares no conflict of interest related to this work.

\author{
Ansewer to Dr.Murat Afyon \\ Ali Bahari ${ }^{1}, \mathrm{MD}$ \\ ${ }^{1}$ Professor, Inflammatory Diseases of the Upper Gastrointestinal \\ Tract Research Center, Mazandaran University of Medical \\ Sciences, 48166 33131, Sari, Iran \\ Tel : + 985138828558 \\ Fax : + 985138598818 \\ Email: baharia@mums.ac.ir \\ Received : 015 Dec. 2015 \\ Accepted : 30 Jan. 2016
}

We thank the author of the letter gratefully for his/her attention and the valuable comments. Surely, we agree with the comments that had been mentioned in the letter. However, the design of our study pointed to somewhat a different issue. We had aimed at investigating the pattern of response to hepatitis $\mathrm{B}$ vaccine in those who had isolated HBC antibodies and to correlate or compare the results with PCR test in order to identify patients with occult HBV infection.

As the author of the letter has mentioned, in occult HBV infection, serum HBV DNA titters may be detectable or even undetectable. Also, occult HBV infec- tion may occur not only seropositive for antibodies to hepatitis B core antigen (anti-HBc) and/or antibodies to HBsAg (anti-HBs), but also seronegative. Therefore, the diagnosis of occult HBV infection would be difficult in patients with both negative HBV DNA titters and negative HBV antigens/antibodies. As we have shown in our article, $19(21.1 \%)$ of the cases had no sero-conversion (anti-HBs titers $<10 \mathrm{mIU} / \mathrm{mL}$ ) 30 days after the third dose, although they had negative PCR results. Accordingly, using vaccination may help to distinguish patients with occult HBV infection among those who have both negative HBV DNA titters and negative HBV antigens and antibodies.

On the other hand, studies have shown that even in the presence of high anti-HBs titers, hepatitis B reactivation occurred after immunosuppressive therapy in anti-HBc positive patients. ${ }^{9}$ Therefore, anti-HBs titters with high titer may not be reliable enough to donate blood safely.

All together, combination of hepatitis $B$ vaccination and HBV DNA PCR may help to exclude patients with occult HBV infection, but the risk of hepatitis B transmission will not be zero.

\section{REFERENCES}

1. Bahari A, Izadi S, Bari Z, Khosravi S, Baghaei B , Saneimoghadam E, et al. Significance of response to hepatitits $B$ vaccine in subjects with isolated antibody to hepatitis B core antigen. Middle East J Dig Dis 2015;7: 233-40.

2. Raimondo G, Allain JP, Brunetto MR, et al. Statements from the Taormina expert meeting on occult hepatitis B virus infection. J Hepatol 2008;49:652-7. doi:10.1016/j. jhep.2008.07.014.

3. Said ZNA. An overview of occult hepatitis B virus infection. World J Gastroenterol 2011;7:1927-38. doi:10.3748/ wjg.v17.i15.1927.

4. Xu L, Wei Y, Chen T, Lu J, Zhu CL, Ni Z, et al. Occult $\mathrm{HBV}$ infection in antiHBs po $\neg$ sitive young adults after neonatal HB vaccination. Vaccine 2010;28:5986-92. doi:10.1016/j.vaccine.2010.06.106.

5. Kleinman SH, Kuhns MC, Todd DS, Glynn SA, McNamara A, DiMarco A, et al. Fre $\neg$ quency of HBV DNA 
detection in US blood donors testing positive for the presence of anti-HBc: implications for transfusion trsmission and donor screening. Transfusion 2003;43:696-704. doi:10.1046/j.1537-2995.2003.00391.x.

6. Levicnik-Stezinar S, Rahne-Potokar U, Candotti D, Lelie $\mathrm{N}$, Allain JP. Anti-HBs positive occult hepatitis B virus carrier blood infectious in two transfusion recipients. $J$ Hepatol 2008;48:1022-5. doi:10.1016/j.jhep.2008.02.016.

7. Guide to the preparation, use and quality assurance of blood components - 17th Edition, European Directorate for Quality of Medicine and Healthcare, 2014.

8. Yugi H, Hino S, Satake M, Tadodoro K. Implementation of donor screening for infectious agents transmitted by blood by nucleic acid technology in Japan. Vox Sang 2005;89:265. doi: 10.1111/j.1423-0410.2005.00694.x.

9. Perillo RP, Gish R, Flack-Ytter YT. American Gastroenterological Association Institute technical review on prevention and treatment of hepatitis B virus reactivation during immunosuppressive drug therapy. Gastroenterology 2015;148:221-44. doi: 10.1053/j.gastro.2014.10.038. 